Review

\title{
A review of the direct oxidation of methane to methanol
}

\author{
Baozhai Han, Yang Yang, Yanyan Xu, U. J. Etim, Ke Qiao, Benjing Xu* , Zifeng Yan* \\ State Key Laboratory of Heavy Oil Processing, College of Chemical Engineering, China University of Petroleum (East China), Qingdao 266580, Shandong, \\ China
}

\section{A R T I C L E I N F O}

Article history:

Received 28 February 2016

Accepted 1 April 2016

Published 5 August 2016

\section{Keywords:}

Methane

Direct oxidation

Methanol

Heterogeneous oxidation

Gas-phase homogeneous oxidation

Aqueous catalyzed oxidation

\begin{abstract}
A B S T R A C T
This article briefly reviewed the advances in the process of the direct oxidation of methane to methanol (DMTM) with both heterogeneous and homogeneous oxidation. Attention was paid to the conversion of methane by the heterogeneous oxidation process with various transition metal oxides. The most widely studied catalysts are based on molybdenum and iron. For the homogeneous gas phase oxidation, several process control parameters were discussed. Reactor design has the most crucial role in determining its commercialization. Compared to the above two systems, aqueous homogenous oxidation is an efficient route to get a higher yield of methanol. However, the corrosive medium in this method and its serious environmental pollution hinder its widespread use. The key challenge to the industrial application is to find a green medium and highly efficient catalysts.
\end{abstract}

(C) 2016, Dalian Institute of Chemical Physics, Chinese Academy of Sciences. Published by Elsevier B.V. All rights reserved.

\section{Introduction}

Natural gas has proven reserves far more than that of crude oil. It consists of $90 \%$ methane and is a promising energy resource to substitute for crude oil. Much attention has been paid to the activation and functionalization of methane to useful hydrocarbons and oxygenated products. One of the most challenging processes of high industrial importance is the conversion of natural gas or methane to methanol, which is an important intermediate source of energy in our daily lives. For example, methanol is an important fuel for heating, automobiles and as the replacement of MTBE (methyl tert-butyl ether) as an additive in petrol.

Conventionally, an indirect route for the conversion of natural gas to methanol is used. The reactions are: (1) intermedi- ate production of synthesis gas by steam reforming, and (2) catalytic conversion of synthesis gas to methanol. However, the production of syngas is an energy-intensive process, which is operated at 65\% thermodynamic efficiency between 800-1000 ${ }^{\circ} \mathrm{C}$ and more than $25 \%$ of the feed (natural gas) has to be burned to provide the heat of reaction. Hence, from the viewpoint of sustainable development, the direct conversion of methane to methanol is a desired alternative to the current technology [1]. There are some promising areas for the application of the direct partial oxidation of hydrocarbon gases, which is displayed in Fig. 1. [2]. In spite of the fact that there are no actual plants yet for the process of direct methane to methanol (DMTM), previous experimental and theoretical works have demonstrated the feasibility of this route [3]. Here, we assess the various methods and catalysts in different systems for the

\footnotetext{
* Corresponding author. Tel: +86-18561601866; E-mail: xubenjing@upc.edu.cn

\# Corresponding author. Tel: +86-532-86981296; Fax: +86-532-86981295; E-mail: zfyancat@upc.edu.cn

This work was supported by the Petrochemical Joint Funds of NSFC-CNPC (U1362202) and the Postgraduate Innovation Project of China University of Petroleum (East China) (YCXJ2016030).

DOI: 10.1016/S1872-2067(15)61097-X | http://www.sciencedirect.com/science/journal/18722067 | Chin. J. Catal., Vol. 37, No. 9, August 2016
} 


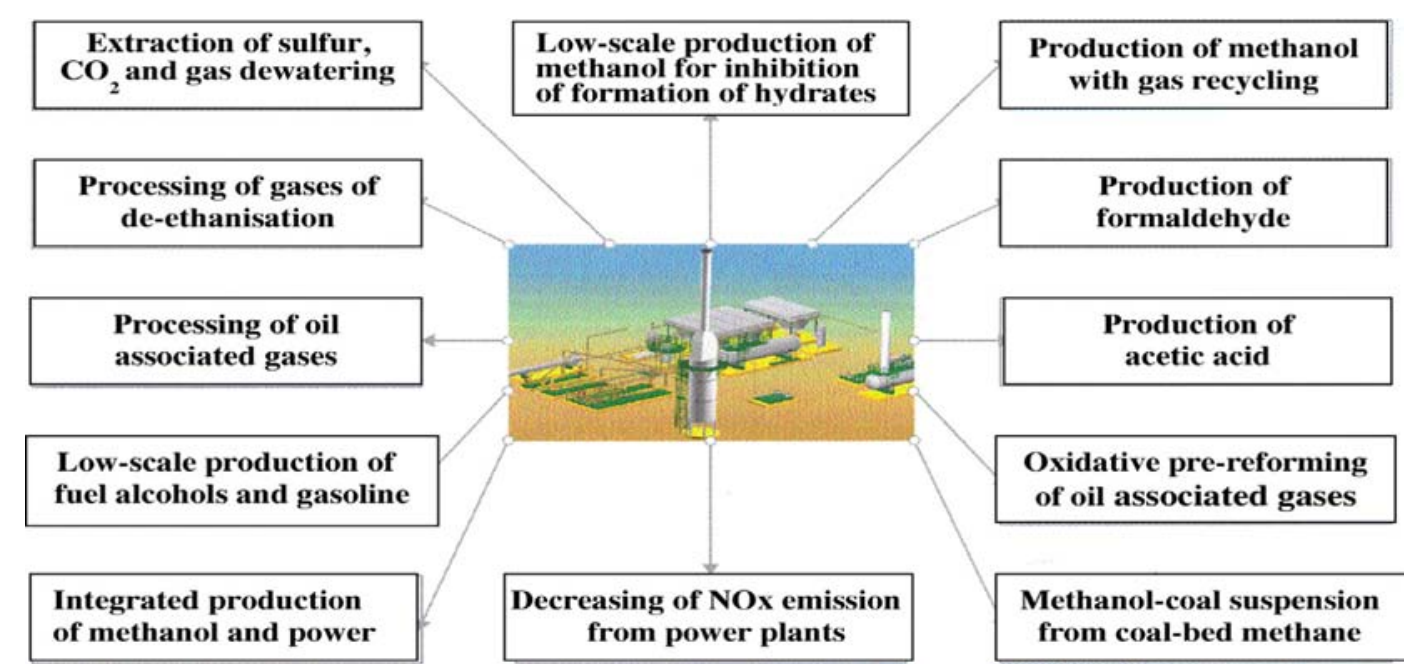

Fig. 1. Promising areas for the application of the direct partial oxidation of hydrocarbon gases. Reprinted with permission from Ref. [2]. Copyright 2007, Elsevier.

DMTM, and provide highlights on the approaches to overcome existing problems to realize industrial utilization of DMTM.

\section{Catalytic oxidation of methane to methanol over heterogeneous catalysts}

In the last century, many publications in this field have discussed the partial oxidation of methane at high temperature over transition metal oxides catalysts. The most widely studied catalysts were those based on molybdenum trioxide and iron compounds.

\subsection{Molybdenum-based catalysts}

Atroshchenko et al. [4] first investigated various metal oxides for the partial oxidation of methane, and reported that $\mathrm{MoO}_{3}$ was one of the best catalysts at elevated temperature and pressure. The authors also found that the successive oxidation of methanol was difficult.

One of the earliest patents was claimed by Dowden and Walker [5], who developed a series of multicomponent oxides based on molybdenum. They stated that the most active catalyst was $\mathrm{Fe}_{2} \mathrm{O}_{3}\left(\mathrm{MoO}_{3}\right)_{3}$, which yielded $869 \mathrm{~g} \mathrm{~kg}^{-1} \mathrm{~h}^{-1}$ of methanol.

In 1982, Liu et al. [6] studied the kinetics and mechanism of the partial oxidation of methane using $\mathrm{N}_{2} \mathrm{O}$ and $\mathrm{MoO}_{3} / \mathrm{SiO}_{2}$ catalysts. They obtained a combined selectivity of $84.6 \%$ towards methanol and formaldehyde. Their results indicated a rate law of the form, $\mathrm{d}\left[\mathrm{CH}_{4}\right] / \mathrm{d} t=-k\left[\mathrm{~N}_{2} \mathrm{O}^{1}\left[\mathrm{CH}_{4}\right]^{0}\right.$. These researchers also found that it was the more reactive $\mathrm{O}^{-}$species that was responsible for initiating the selective oxidation cycle, which was formed by the interaction of $\mathrm{N}_{2} \mathrm{O}$ with surface $\mathrm{MO}(\mathrm{V})$ species.

Liu et al. [7] and Sugino et al. [8] successively reported that the addition of steam to the system with a $\mathrm{MoO}_{3} / \mathrm{SiO}_{2}$ catalyst increased the selectivity to oxygenates by inhibiting further oxidation due to the formation of $\mathrm{H}_{4} \mathrm{SiMo}_{12} \mathrm{O}_{40}$, but most of the product was formaldehyde.

Zhen et al. [9] compared $\mathrm{V}_{2} \mathrm{O}_{5} / \mathrm{SiO}_{2}$ to $\mathrm{MoO}_{3} / \mathrm{SiO}_{2}$ catalysts for the partial oxidation of methane, and concluded that although the former catalyst was more active for methanol production, its product selectivity was generally poorer. The maximum conversion to methanol was only $0.2 \%$ at $460{ }^{\circ} \mathrm{C}$.

Spencer [10] carried out methane partial oxidation using molecular oxygen over a $\mathrm{MoO}_{3} / \mathrm{SiO}_{2}$ catalyst. However, only trace amounts of $\mathrm{CH}_{3} \mathrm{OH}$ was produced. Similar results were obtained by others [11-13], regardless of whether dopants were added to the catalyst.

Later researchers focused on finding more effective support which can replace $\mathrm{SiO}_{2}$ to increase the selectivity to methanol. Taylor et al. [14] investigated the oxidation of methane over a $\mathrm{MoO}_{3}$ catalyst on different supports and found that $\mathrm{Ga}_{2} \mathrm{O}_{3}$ was the best support of $\mathrm{MoO}_{3}$ with the highest selectivity (22\%) to methanol. They suggested that a cooperative effect between $\mathrm{MoO}_{3}$ and $\mathrm{Ga}_{2} \mathrm{O}_{3}$ played a crucial role in increasing the yield of methanol when compared to the other complex metal oxides.

\subsection{Iron-based catalysts}

Otsuka and Wang [15] studied the reaction mechanism for the partial oxidation of methane over an iron sodalite catalyst (Fig. 2). From considering the mechanism of methane monooxygenase for alkane oxidation, Lyons and co-workers $[16,17]$ designed an iron sodalite-based catalyst that showed $70 \%$ selectivity to methanol with $5.7 \%$ methane conversion at $416{ }^{\circ} \mathrm{C}$ and $5.5 \mathrm{MPa}$ using a 3:1 methane-air mixture. They also discussed several similar types of catalysts, and suggested that altering the redox potential of the Fe(II) species can eliminate the requirement of electrons and protons in the biological systems to increase methanol selectivity by mimicking the $\mu$-oxo-bridged binuclear iron centers. Through a combined theoretical and experimental study, Betteridge et al. [3] observed that in a simple flow reactor, there was only a small region where the selectivity was enhanced in the presence of iron sodalite.

Otsuka and Hatano [18] studied the kinetics of the partial oxidation of methane over a $\mathrm{Fe}_{2}\left(\mathrm{MoO}_{4}\right)_{3}$ catalyst. They ob- 


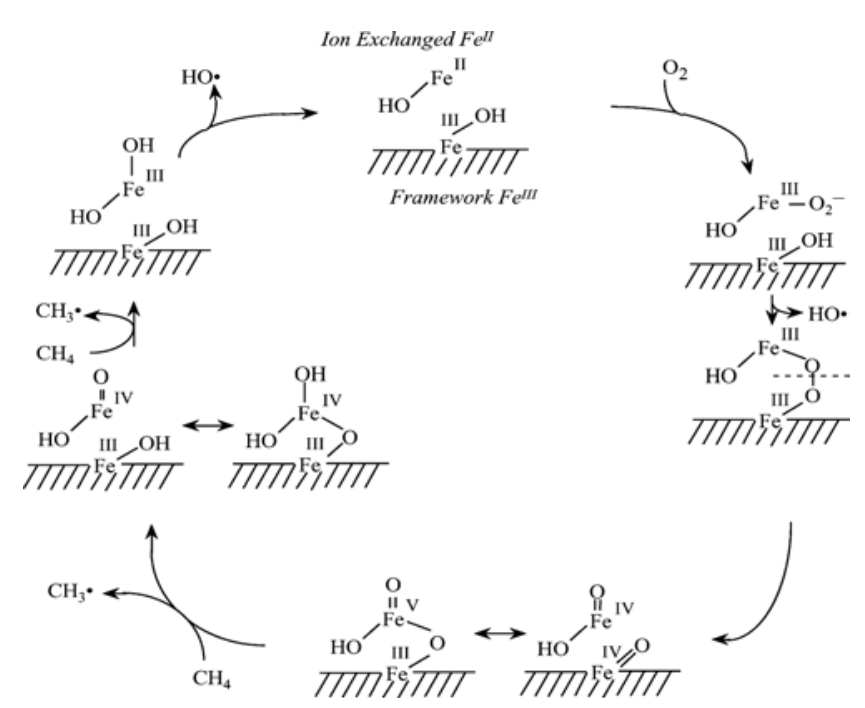

Fig. 2. Hypothetical reaction mechanism for the partial oxidation of methane over iron sodalite catalyst. Reprinted with permission from Ref. [15]. Copyright 2001, Elsevier.

served that $\mathrm{HCHO}$ and $\mathrm{CO}$ were the main products and the rate determining step was the activation of methane by dissociatively adsorbed oxygen.

To prevent the consecutive oxidation of $\mathrm{CH}_{3} \mathrm{OH}$, Wang and Otsuka [19] added a gas mixture of hydrogen and oxygen to a system with different iron-based catalysts, such as Fe-ZSM-5, FAO-5 and $\mathrm{FePO}_{4}$. The results suggested that a new kind of active center was formed in the presence of $\mathrm{H}_{2}$, and methane can be selectively oxidized to methanol on this active center at low temperature.

In order to further increase the activity of iron-based catalysts, iron phosphate supported on MCM-41 was studied for the partial oxidation of methane with both oxygen and nitrous oxide by Wang et al. [20]. The supporting of iron phosphate on MCM-41 with loadings of (20-40) wt\% significantly increased both methane conversion $(3.01 \%)$ and the selectivity to methanol (17.3\%).

Michalkiewicz [21] researched the partial oxidation of methane with molecular oxygen at atmospheric pressure with Fe-ZSM-5 and Fe-NaZSM-5 catalysts. The results showed that although the two catalysts had different effects on methane conversion and methanol selectivity, generally, increasing the iron content in ZSM-5 led to an increase of the activity. However, the consecutive oxidation to $\mathrm{CO}_{2}$ was also inevitable.

Starokon et al. [22] and Parfenov et al. [23] found an interesting phenomenon that methanol generated by hydrolysis of $\left(\mathrm{Fe}-\mathrm{OCH}_{3}\right)_{\alpha}$ groups on the surface of Fe-ZSM-5 migrated from $\alpha$-sites to initiate a new cycle. Furthermore, this work was the first example to succeed in finding the cut-off point between quasicatalytic and catalytic modes in the same system. The selectivity for methanol could be increased to $62 \%$ when water was added.

\section{Non-catalytic oxidation of methane to methanol in gas phase homogeneous oxidation}

Over the past 100 years, the heterogeneous catalytic and homogeneous oxidation of methane to methanol was extensively studied and shown to have practical value [24]. For the heterogeneous catalysis, the examined catalysts include metals, single metal oxides, multiple metal oxides, zeolites and homogeneous complex catalysts. However, owing to irreversible reduction and bulk metal formation, almost all these catalysts showed poor selectivity and the maximum methanol yields were around 5\% in the process [25]. In order to improve the methanol yield, using the progress of engineering technology, many researchers have shown much interest in the gas phase homogeneous oxidation of methane in the absence of catalysts. Economic studies [26-28] showed that the direct route can replace the conventional technology when a minimum conversions of $7.5 \%-10 \%$ and selectivity to methanol of over $70 \%$ can be obtained.

Experiments conducted on the gas phase reaction for the conversion of methane to methanol without a catalyst have shown that this reaction is a degenerate chain branching process [29-31].

The chain reaction is initiated by molecular oxygen at high temperatures:

$$
\begin{aligned}
& \mathrm{CH}_{4}+\mathrm{O}_{2}=\mathrm{CH}_{3} \cdot+\mathrm{HO}_{2} \cdot \\
& \mathrm{CH}_{3}+\mathrm{O}_{2} \leftrightarrow \mathrm{CH}_{3} \mathrm{OO} \cdot
\end{aligned}
$$

The $\mathrm{CH}_{3} \mathrm{OO} \bullet$ radical plays a crucial role in controlling the low temperature kinetics of methane oxidation. It is the key intermediate that determines the operation of the whole chain process for the direct oxidation of methane to methanol. The subsequent reactions for the formation of methanol are:

$$
\begin{aligned}
\mathrm{CH}_{3} \mathrm{OO} \bullet+\mathrm{CH}_{4} & \rightarrow \mathrm{CH}_{3} \mathrm{OOH} \rightarrow \mathrm{CH}_{3} \mathrm{O}^{\bullet}+\mathrm{OH}^{\bullet} \\
\mathrm{CH}_{3} \mathrm{OO}+\mathrm{CH}_{3} \mathrm{OO} & \rightarrow \mathrm{CH}_{3} \mathrm{OH}+\mathrm{CH}_{2} \mathrm{O}+\mathrm{O}_{2} \\
\mathrm{CH}_{3} \mathrm{O}^{\bullet}+\mathrm{CH}_{4} & \rightarrow \mathrm{CH}_{3} \mathrm{OH}+\mathrm{CH}_{3} \bullet \\
\mathrm{CH}_{3} \mathrm{O}^{\bullet}+\mathrm{O}_{2} & \rightarrow \mathrm{CH}_{2} \mathrm{O}+\mathrm{HO}_{2} \bullet
\end{aligned}
$$

During the past decades, much effort were put into increasing the yield of methanol in the homogeneous gas phase partial oxidation of methane. There are some crucial factors that contribute to the wide range of results obtained, such as reactor type, reaction conditions and additives. To facilitate clarity, each of these parameters will be discussed individually.

\subsection{Reactor design}

Much earlier work was carried out using stainless steel and gave a very low selectivity for methanol, mainly owing to the undesirable side reactions of the deep catalytic oxidation of methane which occurs on the metal surface. Zhang et al. [32] stated that methanol was easier to adsorb than methane on the surface of the catalyst or reactor wall and to activate and oxidize. So, a number of studies concentrated on the reactor materials that would minimize the deep oxidation of methanol to increase the selectivity. The results indicated that the optimal choice for reactor material was Pyrex [33-35] or quartz [36,37] linings, which would ensure the reaction was homogeneous.

A special reactor (Fig. 3.) was designed by Zhang et al. [38] to carry out gas phase oxidation of methane to methanol, which gave a comparatively high selectivity of methanol (60\%) over a quite wide temperature range at 5.0 $\mathrm{MPa}$ and $\mathrm{CH}_{4}: \mathrm{O}_{2}: \mathrm{N}_{2}=$ 


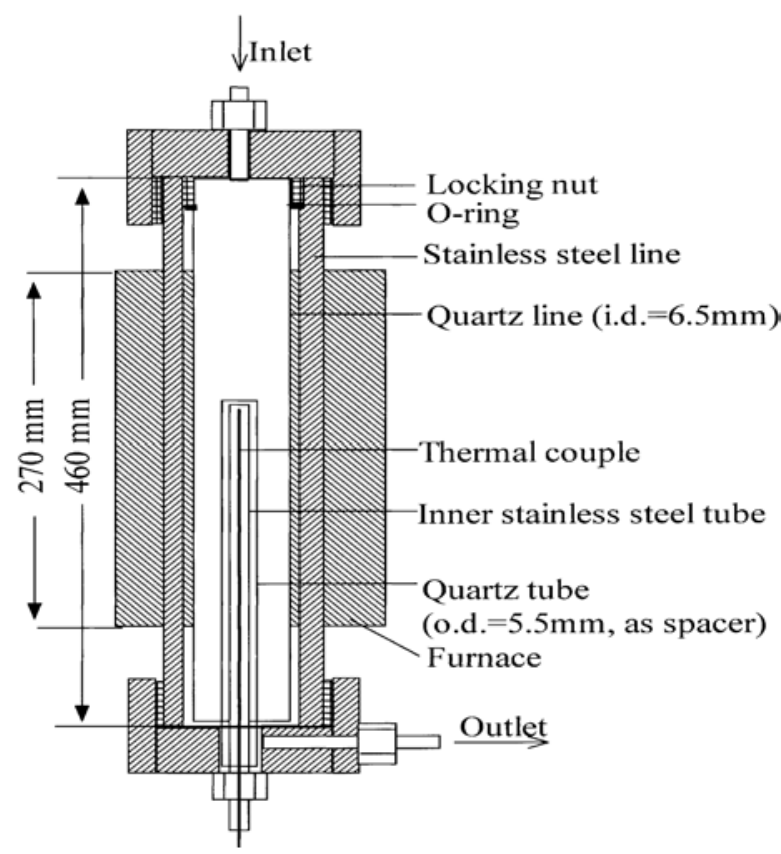

Fig. 3. Diagram of the reactor. Reprinted with permission from Ref. [38] Copyright 2002, Elsevier.

100:10:10 (mL/min). As compared to the "two-step" route via syngas, a "single-pass" concept for producing methanol was proposed [39], which is shown in Fig. 4.

Arutyunov [1] provided a better understanding of the direct conversion of methane to methanol by designing a complex reactor to increase the conversion of methane. This process needs a higher amount of oxygen per pass to increase the conversion of methane. However, a low actual concentration of oxygen is necessary to prevent a substantial temperature rise. By only fractionally introducing oxygen and partially removing heat before adding the next portion of oxygen satisfied these demands, as shown in Fig. 5. Also, by forming a "cold-gas cylinder" to isolate the reaction mixture from the reactor walls, the temperature can be decreased, especially in the case that the conversion of the gas was not complete to produce some methanol [40]. This construction decreases the contribution from surface oxidation and ease the demands for the construction materials for the reactor.

\subsection{Reaction conditions}

Based on the earlier work done on the homogeneous gas

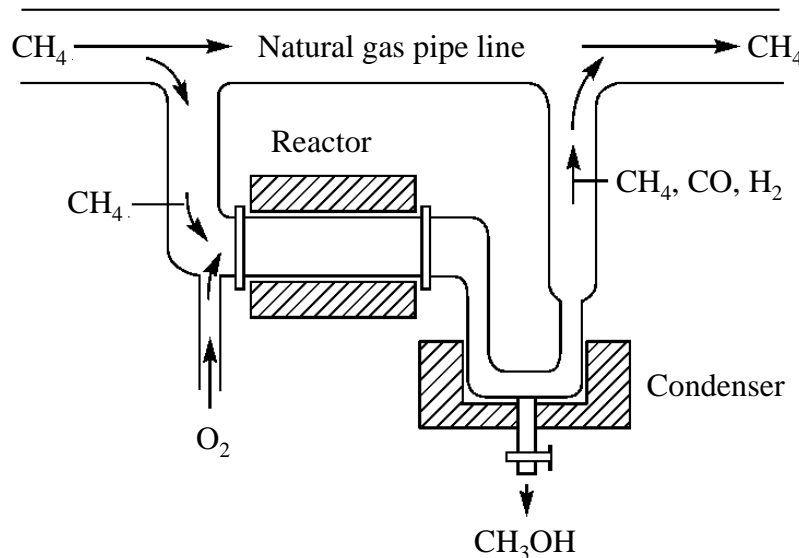

Fig. 4. "Single-pass" concept for producing methanol from pipe-line natural. Reprinted with permission from Ref. [39]. Copyright 2003, PEI-CHING HUA KUNG YEN CHIU YUA.

phase oxidation of methane to methanol, a summary of some significant results obtained is given in Table 1 [41].

The narrow temperature interval is not a decisive factor for this process, but the initial temperature has to be above $400{ }^{\circ} \mathrm{C}$ to initiate the radical chain reaction. The equilibrium temperature should be less than $550{ }^{\circ} \mathrm{C}$ to avoid deep oxidation of the oxygenates. Once the reactor temperature is determined, the conversion of methane is dependent on the other variables in the reactor. According to Table 1, the highest selectivity of methanol is obtained at $500-550{ }^{\circ} \mathrm{C}$.

High pressure plays an important role in providing the necessary conditions for chain branching. Increasing the reactor pressure can reduce the temperature at which the highest selectivity of methanol is obtained. In addition, increasing the pressure results in a sharp increase in methanol yield due to the kinetics. When the pressure is increased to $5 \mathrm{MPa}$, the optimal temperature drops to $370{ }^{\circ} \mathrm{C}$. However, when the pressure is above $8 \mathrm{MPa}$, the higher yield of methanol cannot compensate for the expenses consumed by compression equipment [40]. Due to these variables being inextricably linked, the effect of pressure on the DMTM process is complex. Arutyunov [49] carried out studies in laboratory scale stainless steel and quartz flow reactors at 1.5-8.0 MPa to analyze the effect of reactor surface material and pressure on the partial oxidation of methane.

In considering the explosive limits of methane, the upper oxygen limit is $10 \%$. Consequently, the majority of the studies

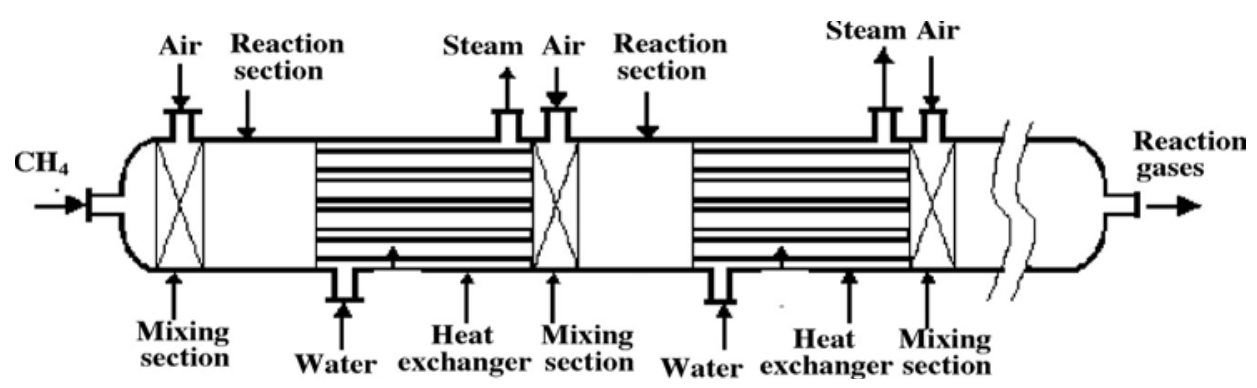

Fig. 5. DMTM reactor with the fractional introduction of oxygen and removal of heat excess in the steam-generating sections. Reprinted with permission from Ref. [40]. Copyright 2013, Elsevier. 
Table 1

Summary of important results reported for the gas phase oxidation of methane to methanol [41].

\begin{tabular}{|c|c|c|c|c|c|c|}
\hline Reference & $\mathrm{CH}_{4}$ conversion $(\%)$ & $\mathrm{CH}_{3} \mathrm{OH}$ selectivity (\%) & Temperature $\left({ }^{\circ} \mathrm{C}\right)$ & Pressure (MPa) & $\mathrm{O}_{2}$ in feed $(\%)$ & Flow rate $(\mathrm{mL} / \mathrm{min})$ \\
\hline Foulds et al. [37] & up to 9.0 & up to 47 & $350-480$ & $1.5-5.0$ & $2.5-9.5$ & $200-1000$ \\
\hline Charlton et al. [42] & up to 9.0 & up to 17 & $440-480$ & 3.0 & 9.5 & 200 \\
\hline Chun and Anthony [43] & up to 4.5 & $34-55$ & $350-500$ & 5.0 & $2.3-4.4$ & - \\
\hline Chun and Anthony [35] & up to 9.0 & $30-35$ & $367-477$ & 5.0 & 4.35 & 307 \\
\hline Walsh et al. [33] & up to12.2 & $8.4-34.9$ & 465 & 6.2 & $3.8-14.6$ & $402-798$ \\
\hline Thomas et al. [44] & up to 7.0 & up to 20 & $400-650$ & 2.0 & up to 10 & - \\
\hline Rytz and Baiker [36] & up to 14.0 & up to 50.0 & $425-500$ & $2.0-5.0$ & $3.0-10$ & 25 \\
\hline Hunter et al. [45] & up to 11.0 & up to 83.0 & $410-480$ & $3.4-6.6$ & $2.1-10.3$ & up to 500 \\
\hline Baldwin et al. [46] & up to 5.5 & up to 55.5 & $375-500$ & $0.5-5.0$ & $2.5-6.6$ & - \\
\hline Fukuoka et al. [47] & up to 6.3 & up to 32.4 & $350-500$ & $2.1-4.1$ & $1.5-9.0$ & - \\
\hline Yarlagadda et al. [48] & $8.0-10.0$ & $70-80$ & $400-500$ & $2.5-6.5$ & $2.5-10.0$ & $10-44$ \\
\hline
\end{tabular}

in Table 1 chose a feed oxygen concentration ranging from $1 \%-10 \%$. Generally, when the feed oxygen concentration is increased, a higher conversion of methane is obtained with a lower selectivity for methanol.

Another important factor is the reaction time, which has two models: "short-time" model (several seconds) and "long-time" model (minutes) based on the study of Rytz and Baiker [36]. In the "short-time" model, in which the duration of the process does not exceed the time of diffusion of the reaction intermediates to the surface, the conversion of methane gets higher as the reaction time gets longer, but the selectivity of methanol gets lower. The yield of methanol is not more than $2.5 \%$, which is consistent with gas phase kinetic simulation results. In the "long-time" model, in which the duration of the process exceeds the time of diffusion of the intermediates to the walls, the methane conversion is constant as the reaction time increases and there is no limit to the yield of methanol. These results are not consistent with gas phase kinetic simulation results, and this model is the description of heterogeneous reactions.

\subsection{Additives}

Natural gas is a hydrocarbon gas mixture consisting primarily of methane, containing some ethane and higher hydrocarbons. In a study on the effect of additives on the partial oxidation of methane, Fukuoka et al. [47] found that the additives can lower the initiation temperature and donate hydrogen to the methoxy radical.

Burch et al. [50] reported that the ignition temperature can be lowered by $50{ }^{\circ} \mathrm{C}$ with $5 \%$ ethane in methane while the methanol selectivity was unaffected. Foral [51] investigated the effect of ethane in the feed. The results indicated that methane conversion decreased as the ethane content increased, but the total conversion (methane and ethane) increased. Methanol selectivity remained unchanged. A study has demonstrated the trend between the initial oxygen concentration and composition of the oxidation products of methane-ethane mixtures. There was a decrease in the $\left[\mathrm{CH}_{3} \mathrm{OH}\right] /[\mathrm{CO}]$ ratio with the increase in the initial concentration of oxygen during the partial oxidation, which can be seen from Table 2 [52].

Fokin et al. [53] conducted studies on the partial gas phase oxidation of hydrocarbons $\left(\mathrm{C}_{1}-\mathrm{C}_{4}\right)$ mixtures at a specific com- position to investigate the effect of different parameters on the $\left[\mathrm{CH}_{3} \mathrm{OH}\right] /[\mathrm{CO}]$ ratio and product distribution. The results showed that a lower initiation temperature can contribute to a high yield of methanol and the $\left[\mathrm{CH}_{3} \mathrm{OH}\right] /[\mathrm{CO}]$ ratio was strongly affected by the initial concentration of oxygen. Therefore, in order to obtain a high yield of methanol, it is necessary to control the additives in the reaction mixture, especially the additives-to-oxygen ratio.

In recent years, many researchers found that the addition of $\mathrm{NO}_{x}$ can remarkably increase methane conversion and selectivity to methanol. Teng et al. [54] observed that when $0.25 \%$ NO was injected into the $\mathrm{CH}_{4}-\mathrm{O}_{2}$ system, the methane conversion increased from only $1 \%$ at $693{ }^{\circ} \mathrm{C}$ to $10 \%$ at $535^{\circ} \mathrm{C}$. The effects of $\mathrm{NO}_{2}$ on the oxidation of methane were also investigated [54]. It was shown that the addition of $\mathrm{NO}_{2}$ decreased the reaction initiation temperature by $300{ }^{\circ} \mathrm{C}$ and it improved the $\mathrm{CH}_{4}$ conversion as well as the target product yield.

\section{Aqueous catalyzed oxidation}

In gas-solid phase heterogeneous catalytic oxidation, owing to the strong chemical stability of methane, the process of DMTM often needs to be activated at high reaction temperature. However, in the liquid phase, this reaction can occur at moderate reaction conditions, and the medium can eliminate diffusion resistance of the reactants to increase the activity of the catalyst.

Homogeneous catalysis mediated by a transition metal complex is one of the most efficient ways to improve the yield of methanol. Depending on the nature of the metal $\mathrm{M}$ and the

Table 2

Dependence of the distribution of products on the composition of the initial mixture [52].

\begin{tabular}{|c|c|c|c|c|c|}
\hline \multicolumn{3}{|c|}{$\begin{array}{l}\text { Gas mixture composition at } \\
\text { the reactor inlet (the rest is } \\
\left.\mathrm{N}_{2}\right)(\%)\end{array}$} & \multicolumn{2}{|c|}{$\begin{array}{l}\text { Concentration in the } \\
\text { mixture at the reactor } \\
\text { outlet }(\%)\end{array}$} & \multirow[t]{2}{*}{$\begin{array}{c}{\left[\mathrm{CH}_{3} \mathrm{OH}\right]} \\
/[\mathrm{CO}]\end{array}$} \\
\hline $\mathrm{CH}_{4}$ & $\mathrm{C}_{2} \mathrm{H}_{6}$ & $\mathrm{O}_{2}$ & $\mathrm{CH}_{3} \mathrm{OH}$ & $\mathrm{CO}$ & \\
\hline 13.4 & 69.1 & 3.8 & 1.4 & 2.3 & 0.6 \\
\hline 12.0 & 64.0 & 5.8 & 1.7 & 4.5 & 0.4 \\
\hline 10.2 & 52.0 & 8.2 & 1.9 & 5.7 & 0.3 \\
\hline 44.3 & 8.5 & 6.1 & 1.4 & 3.8 & 0.4 \\
\hline 44.8 & 1.3 & 9.2 & 0.3 & 4.6 & 0.1 \\
\hline
\end{tabular}


ligand set $L_{n}$ in the active $L_{n} M$ species, different situations are encountered. The $\mathrm{C}-\mathrm{H}$ activation processes are classified according to four main different mechanisms: oxidative addition, $\sigma$-bond metathesis, electrophilic substitution and 1,2-addition. Electrophilic substitution is the most popular in the homogeneous catalysis of DMTM. The mechanism is illustrated in Fig. 6.

In the liquid phase oxidaiton of methane, metal ions as a very strong electrophilic reagent makes an electrophilic attack on methane, generating the corresponding intermediates of the metal complex. Then, these intermediates are transformed to stable compounds by nucleophilic reagents. The recycle of the catalyst can be achieved through the oxidation of the reduced metal ions to a high chemical valence. Nucleophilic reagents play an important role in the process. So, according to the different nucleophilic reagents, the homogeneous catalysis of DMTM can be roughly classified into a strong acid system, water system and ionic liquid system.

\subsection{Strong acid system}

At present, many researchers focus their attention on the homogeneous catalysis in a strong acid system which is influenced by two main factors: (1) the coordination ability of the conjugate base of a strong acid is so weak that it can improve the electrophilicity of the metal ions to promote the activity of the catalyst, and (2) esterification products of methanol generated by the strong acid can avoid the excessive oxidation of methanol to improve the selectivity.

\subsubsection{Oleum system}

In 1993, by using $\mathrm{H}_{2} \mathrm{SO}_{4}$ as the oxidant, Periana et al. [56] succeeded in converting $\mathrm{CH}_{4}$ to $\mathrm{CH}_{3} \mathrm{OSO}_{3} \mathrm{H}$ in a concentrated sulfuric acid medium with a $\mathrm{HgSO}_{4}$ catalyst. The selectivity to $\mathrm{CH}_{3} \mathrm{OSO}_{3} \mathrm{H}$ reached $85 \%$ at a $\mathrm{CH}_{4}$ conversion of $50 \%$ at $180{ }^{\circ} \mathrm{C}$. The details of the reaction kinetics and design of the reactor for the DMTM process have been reported by Gang et al. [57].

To overcome the loss of active components due to the reduction of noble metal ions, a new catalyst-bipyrimidyl PtII complex was designed to replace $\mathrm{HgSO}_{4}$ for the conversion of $\mathrm{CH}_{4}$ in oleum by Periana et al. [58]. The reaction mechanism for this catalytic process is shown in Fig. 7. The turnover numbers (TONs) reached 300 at $81 \%$ selectivity with methyl bisulfate as a highly promising system with the highest activity so far.

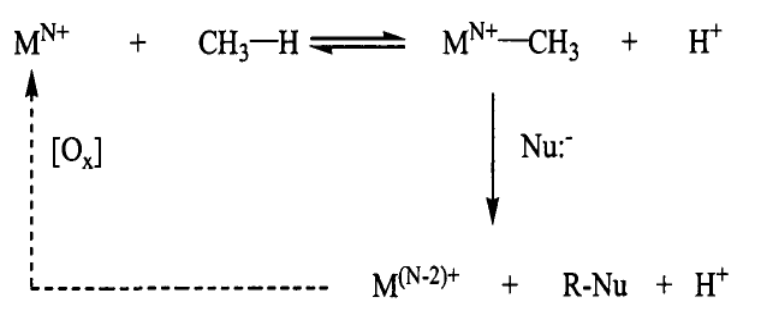

\section{$\mathrm{Ox}=2 \mathrm{e}^{-}$oxidant; $\mathrm{Nu}^{-}=$nucleophile.}

Fig. 6. Electrophilic substitution for the activation of alkane's C-H bonds. Reprinted with permission from Ref. [55]. Copyright 2011, Elsevier.

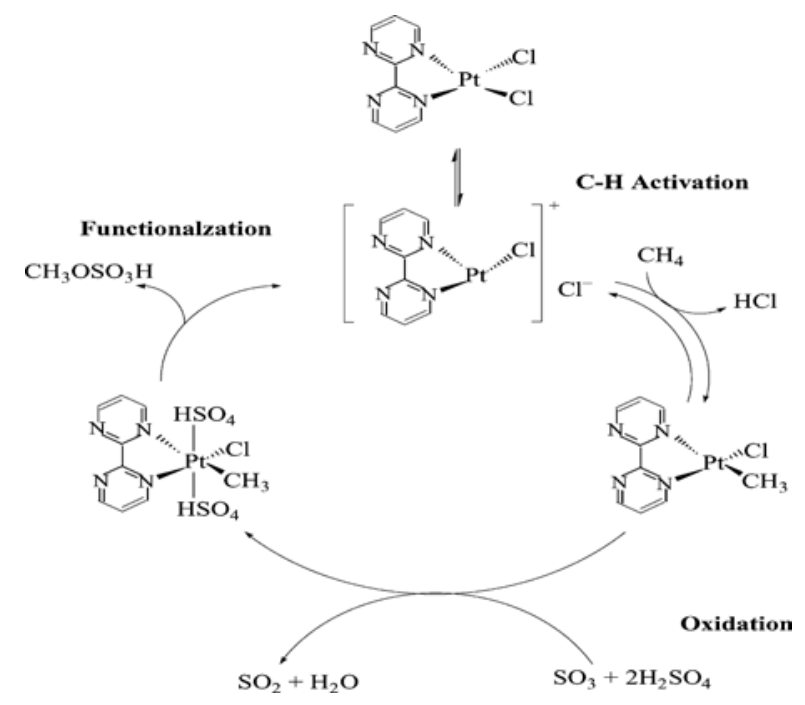

Fig. 7. Reaction mechanism for the oxidation of methane to methyl bisulfate with a Pt-complex catalyst in oleum. Reprinted with permission from Ref. [58]. Copyright 1998, AAAS.

Compared with non-liganded Pt salts, the key role of the Pt-bipyrimidine ligand is to maintain the solubility of the Pt(II) species. The presence of the ligand in the transition state for $\mathrm{C}-\mathrm{H}$ activation can enable the selectivity of the $\mathrm{C}-\mathrm{H}$ activation reaction to be controlled. To obtain insight regarding structure-activity relationships of this kind of solid catalyst, further investigations were made by Palkovits et al. [59], demonstrating that the ligand can increase the electron density on the Pt and the stability of the catalyst which are both important for the process of DMTM.

Subsequently, many studies were focused on iodine and iodine-containing compounds for the process of DMTM in oleum. Periana et al. [60] reported that 1-10 mmol elemental iodine dissolved in sulfuric acid containing $2 \%-3 \% \mathrm{SO}_{3}$ (oleum) can generate a stable active species that at $165-220{ }^{\circ} \mathrm{C}$ catalyzed the functionalization of methane (3.45 MPa) to methyl bisulfate. This gave $45 \%$ yield at $>90 \%$ selectivity. Gang et al. [61] got similar results when a series of iodine-containing compounds were applied in oleum, and both authors concluded that it was $\mathrm{I}_{2}{ }^{+}$as the electrophilic reagent that catalyzed methane to methyl bisulfate. In optimizing the process, Cao [62] found that $70.5 \%$ yield of methanol at $82.7 \%$ conversion of methane can be obtained at $200{ }^{\circ} \mathrm{C}$ in oleum containing $50 \mathrm{wt} \%$ $\mathrm{SO}_{3}$. He suggested that the reaction mechanism in this system was electrophilic substitution and not radical degenerate chain branching.

In 2004, a uniquely efficient electrophilic catalyst for methane conversion was developed. This was gold cations in a strong acid solvent using $\mathrm{Se}^{\mathrm{VI}}$ ions as the stoichiometric oxidant. This was different from several such systems based on the cations $\mathrm{HgII}, \mathrm{Pd}^{\mathrm{II}}$ and $\mathrm{Pt}^{\mathrm{II}}$ with more than $90 \%$ selectivity to methanol [63].

In addition to the above noble metal catalysts, some transition metal oxides [64], transition metal sulfates [65] and heteropolyacids [66] have been proved to have roles in the DMTM process. 


\subsubsection{Trifluoroacetic acid system}

In 1989, Sen and coworkers [67] found that methane can be converted into methyl trifluoroacetate in trifluoroacetic acid (aq) with using $\mathrm{Pd}(\mathrm{OAc})_{2}$ as catalyst, $\mathrm{O}_{2}$ or $\mathrm{H}_{2} \mathrm{O}_{2}$ as oxidant, and the TON was $0.6 \mathrm{~h}^{-1}$.

In 1990, Vargaftik et al. [68] discovered that methane can be oxidized stoichiometrically by cobalt(III) trifluoroacetate in $\mathrm{CF}_{3} \mathrm{COOH}$ solution at $150-180{ }^{\circ} \mathrm{C}$ and $1-4 \mathrm{MPa}$ to give methyl trifluoroacetate in $(90 \pm 10) \%$ yield. In the presence of $\mathrm{O}_{2}$ (0.1-0.5 MPa), methyl trifluoroacetate was the sole product of the oxidation of methane.

In 1995, Yamanaka et al. [69] designed a new catalyst system, $\mathrm{EuCl}_{3}-\mathrm{Zn}-\mathrm{CF}_{3} \mathrm{CO}_{2} \mathrm{H}$. They found that $\mathrm{MeOH}$ was only produced in the liquid phase with no production of HCHO. The TON based on $\mathrm{EuCl}_{3}$ for the formation of $\mathrm{MeOH}$ was $4.0 \mathrm{~h}^{-1}$. A year later, Lin et al. [70] increased the TON to $7.5 \mathrm{~h}^{-1}$ using $\mathrm{RhCl}_{3}$.

Based on the work of Gretz et al. [71], An et al. [72] built an electron transfer chain which used dioxygen for methane oxidation to methanol at low temperature. With the combination of three redox couples $\mathrm{Pd}^{2+} / \mathrm{Pd}^{0}, \mathrm{Q} / \mathrm{H}_{2} \mathrm{Q}$, and $\mathrm{NO}_{2} / \mathrm{NO}$ in $\mathrm{CF}_{3} \mathrm{COOH}$, the authors developed a catalyst for a one-pot aerobic oxidation of methane at $80{ }^{\circ} \mathrm{C}$. The TON was 0.7 per hour. Afterwards, a new electron transfer chain was designed, namely, Pd/C-benzoquinone- $\mathrm{CO}-\mathrm{O}_{2}$, which increased the catalytic efficiency and avoided the loss of active components.

In 2013, a direct selective aerobic oxidation reaction of methane to methanol with a $\mathrm{Pd}(\mathrm{OAc})_{2} / \mathrm{BQ} / \mathrm{H}_{5} \mathrm{PMo}_{10} \mathrm{~V}_{2} \mathrm{O}_{40}$ catalyst using oxygen in $\mathrm{CF}_{3} \mathrm{COOH} / \mathrm{C}_{8} \mathrm{~F}_{18}$ was studied by Yuan et al. [73]. The results suggested that methyl trifluoroacetate was the only liquid product. As an oxygen carrier, perfluorooctane can improve the yield of methyl trifluoroacetate significantly.

From the above discussion, it is obvious that a much higher conversion of methane and selectivity to methanol can be obtained in a strong aid media system. However, the use of a strong acid or heavy metal as the catalyst gives problems of severe corrosion and serious pollution. Consequently, exploring green processes for methane conversion has attracted considerable interest.

\subsection{Water system}

In 1969, methane was successfully converted to methanol in an aqueous medium using $\mathrm{H}_{2} \mathrm{PtCl}_{4}$ as catalyst [74]. In 2004, on the basis of the work of the Periana's group [58], Neumann et al. [75] designed a new catalyst, bipyrimidinylplatium-polyoxometalate $\left(\mathrm{H}_{5} \mathrm{PV}_{2} \mathrm{Mo}_{10} \mathrm{O}_{40}\right)$ hybrid complex, which was effectively used in the mild aerobic $\left(50-60{ }^{\circ} \mathrm{C}, 0.1-0.2 \mathrm{MPa}\right.$ of $\mathrm{O}_{2}$ ) aqueous oxidation of methane to methanol. The TON was as high as 33.

In 2010, Sorokin and co-workers [76] discovered the first bio-inspired catalytic system for the mild oxidation of methane to methanol in water at $25-60{ }^{\circ} \mathrm{C}$ using an N-bridged diiron phthalocyanine complex as the catalyst. This showed an unexpected activity and provided a novel promising approach in the field of methane oxidation.

In 2012, the partial oxidation of methane to methanol was studied by Hammond et al. [77] using copper-promoted Fe-ZSM-5 catalyst in an aqueous medium. The results demonstrated that the interaction between Fe-ZSM-5 and hydrogen peroxide resulted in a low energy pathway for methane oxidation, which was distinguished from Fenton's chemistry, an oxygen and an MMO-type rebound mechanism.

Water as a medium is economically and environmentally friendly. It has been applied successfully in the process of DMTM on the laboratory scale. In this system, $\mathrm{H}_{2} \mathrm{O}_{2}$ as the oxidant is easily decomposed by metal ions which are necessary for the catalytic oxidation of methane. As regards the disadvantage of a low conversion of methane, this process would be more attractive if $\mathrm{H}_{2} \mathrm{O}_{2}$ is replaced by another stable oxidant and a catalyst with high activity is developed.

\subsection{Other systems}

Shilov and Shul'pin [78] studied the direct oxidation of methane to methanol in acetonitrile solution under mild conditions in the presence of ${ }^{n} \mathrm{Bu}_{4} \mathrm{NVO}_{3}$ as catalyst. The effect of promotors on the reaction, such as pyrazine-2-carboxylic acid (PCA), manganese(IV) complex and vanadium-containing polyphosphomolybdate was investigated. It was found that the total TON was 376 in the presence of PCA, which was the best promotor among other substituted pyrazinecarboxylic acids [79].

Li et al. [80] have an interesting work on this reaction with iodine as catalyst in a mixed solvent consisting of acetic acid and $\mathrm{H}_{3} \mathrm{P}_{6} \mathrm{~W}_{8} \mathrm{Mo}_{12} \mathrm{O}_{70}$. They obtained a methane conversion of $32.79 \%$ and the target product selectivity of $96.64 \%$ at $210{ }^{\circ} \mathrm{C}$ and reaction pressure $4.0 \mathrm{MPa}$.

$\mathrm{Li}$ and coworkers [55] designed a green chemical process employing nano-particle gold as catalyst and [Bmim] $\mathrm{Cl}$ ionic liquid (IL) as solvent for methane oxidation. The results showed that the ionic liquid acted as a dissolution medium for the nano- $\mathrm{Au} / \mathrm{SiO}_{2}$ catalyst, and promoted the activity of gold. They obtained a methane conversion of $24.9 \%$ and methanol selectivity of $71.5 \%$. Furthermore, the gold particles and IL can be recycled. The recovery was $96.9 \%$.

For the liquid phase oxidation of methane, many researchers have concentrated on developing green chemical processes. Finding a suitable solvent system is a task of top priority. Although acetonitrile solution, acetic acid, heteropolyacid and ionic liquid were all applied in the oxidation of methane successfully, with high selectivity of methanol, these systems are still at the stage of experiments, and still far from practical production.

\section{Concluding remarks}

The controlled partial oxidation of methane to methanol has been studied for many decades. However, there is still a long way to go to get a reasonable methanol yield with high selectivity. The high stability of the $\mathrm{C}-\mathrm{H}$ bond $(435 \mathrm{~kJ} / \mathrm{mol})$ in methane and the easy over-oxidation to form $\mathrm{CO}_{2}$ make it hard to get a high yield of methanol. Many efforts have been made to solve the problems and some promising results and significant ad- 
vances were obtained. However, there are still critical matters that prohibit its large scale use.

In heterogeneous oxidation, the most widely studied catalysts are those based on molybdenum and iron. Considerable progress has been made in the design of catalysts, optimization of reaction conditions and analysis of the reaction mechanism, but the process still suffers from low selectivity and yield.

In gas phase homogeneous oxidation, several process controlling parameters were discussed, including reactor design, reaction pressure, reaction temperature and additives. The studies indicated that a low temperature is conducive to methanol production, so long as ignition can occur. So decreasing the ignition temperature should have further research emphasis. It was reported that increasing the reactor pressure can reduce the temperature at which the highest selectivity of methanol is obtained. Besides, a higher product selectivity can only be obtained under a lower conversion per pass. So, a new reactor design is recommended to improve the conversion of methane, such as using membrane reactors to have the advantage of separating methanol from the mixed gases in the reactor. In addition, the effects of additives on the oxidation process were discussed.

Compared to the above two systems, aqueous homogenous oxidation affords the most efficient route to higher yields of methanol. However, the strongly corrosive medium used in this system seriously pollutes the environment and therefore hinders its widespread use. Nevertheless, a green approach promoted by a highly efficient catalyst system will enhance its commercialization.

\section{References}

[1] V. S. Arutyunov, Direct Methane to Methanol: Foundations and Prospects of the Process, Elsevier, 2014.

[2] V. S. Arutyunov, Stud. Surf. Sci. Catal., 2007, 167, 269-274.

[3] S. Betteridge, C. R. A. Catlow, D. H. Gay, R. W. Grimes, J. S. J. Hargreaves, G. J. Hutchings, R. W. Joyner, Q. A. Pankhurst, S. H. Taylor, Top. Catal., 1994, 1, 103-110.

[4] V. I. Atroshchenko, Z. M. Shchedrinskaya, N. A. Gavrya, J. Appl. Chem., 1965, 38, 643-649.

[5] D. A. Dowden, G. T. Walker, British Patent 1244 001, 1971.

[6] R. S. Liu, M. Iwamoto, J. H. Lunsford, J. Chem. Soc., Chem. Commun., 1982, 78-79.

[7] H. F. Liu, R. S. Liu, K. Y. Liew, R. E. Johnson, J. H. Lunsford, J. Am. Chem. Soc., 1984, 106, 4117-4121.

[8] T. Sugino, A. Kido, N. Azuma, A. Ueno, Y. Udagawa, J. Catal., 2000, 190, 118-127.

[9] K. J. Zhen, M. M. Khan, C. H. Mak, K. B. Lewis, G. A. Somorjai, J. Catal., 1985, 94, 501-507.

[10] N. D. Spencer, J. Catal., 1988, 109, 187-197.

[11] E. M. Coda, E. Mulhall, R. van Hoek, B. K. Hodnett, Catal. Today, 1989, 4, 383-387.

[12] M. A. Banares, J. L. G. Fierro, J. B. Moffat, J. Catal., 1993, 142, 406-417.

[13] Y. Barbaux, A. R. Elamrani, E. Payen, L. Gengembre, J. P. Bonnelle, B. Grzybowska, Appl. Catal., 1988, 44, 117-132.

[14] S. H. Taylor, J. S. J. Hargreaves, G. J. Hutchings, R. W. Joyner, C. W. Lembacher, Catal. Today, 1998, 42, 217-224.

[15] K. Otsuka, Y. Wang, Appl. Catal. A, 2001, 222, 145-161.
[16] V. A. Durante, D. W. Walker, S. M. Gussow, J. E. Lyons, US Patent $4918249,1990$.

[17] J. E. Lyons, P. E. Ellis, V. A. Durante, Stud. Surf. Sci. Catal., 1991, 67, 99-116.

[18] K. Otsuka, M. Hatano, J. Catal., 1987, 108, 252-255.

[19] Y. Wang, K. Otsuka, J. Chem. Soc., Chem. Commun., 1994, 2209-2210.

[20] X. X. Wang, Y. Wang, Q. H. Tang, Q. Guo, Q. H. Zhang, H. L. Wan, J. Catal., 2003, 217, 457-467.

[21] B. Michalkiewicz, Appl. Catal. A, 2004, 277, 147-153.

[22] E. V. Starokon, M. V. Parfenov, S. S. Arzumanov, L. V. Pirutko, A. G. Stepanov, G. I. Panov, J. Catal., 2013, 300, 47-54.

[23] M. V. Parfenov, E. V. Starokon, L. V. Pirutko, G. I. Panov, J. Catal., 2014, 318, 14-21.

[24] V. S. Arutyunov, O. V. Krylov, Russ. Chem. Rev., 2005, 74, 1111-1137.

[25] R. Palkovits, M. Antonietti, P. Kuhn, A. Thomas, F. Schüth, Angew. Chem. Int. Ed., 2009, 48, 6909-6912.

[26] J. H. Edwards, N. R. Foster, Fuel Sci. Technol. Int., 1986, 4, 365-390.

[27] J. W. M. H. Geerts, J. H. B. J. Hoebink, K. van der Wiele, Catal. Today, 1990, 6, 613-620.

[28] J. C. W. Kuo, C. T. Kresge, R. E. Palermo, Catal. Today, 1989, 4, 463-470.

[29] N. R. Foster, Appl. Catal., 1985, 19, 1-11.

[30] H. D. Gesser, N. R. Hunter, C. B. Prakash, Chem. Rev., 1985, 85, 235-244.

[31] M. J. Brown, N. D. Parkyns, Catal. Today, 1991, 8, 305-335.

[32] Q. J. Zhang, D. H He, Q. M. Zhu, J. Nat. Gas Chem., 2003, 12, 81-89.

[33] D. E. Walsh, D. J. Martenak, S. Han, R. E. Palermo, Ind. Eng. Chem. Res., 1992, 31, 1259-1262.

[34] J. W. Chun, R. G. Anthony, Ind. Eng. Chem. Res., 1993, 32, 259-263.

[35] J. W. Chun, R. G. Anthony, Ind. Eng. Chem. Res., 1993, 32, 796-799.

[36] D. W. Rytz, A. Baiker, Ind. Eng. Chem. Res., 1991, 30, 2287-2292.

[37] G. A. Foulds, B. F. Gray, S. A. Miller, G. S. Walker, Ind. Eng. Chem. Res., 1993, 32, 780-787.

[38] Q. J. Zhang, D. H. He, J. L. Li, B. Q. Xu, Y. Liang, Q. M. Zhu, Appl. Catal. A, 2002, 224, 201-207.

[39] X. Zhang, D. H. He, Q. J. Zhang, Q. M. Zhu, Petrochem. Technol,, 2003, 32, 195-199.

[40] V. S. Arutyunov, Catal. Today, 2013, 215, 243-250.

[41] G. A. Foulds, B. F. Gray, Fuel Process. Technol., 1995, 42, 129-150.

[42] B. G. Charlton, G. A. Foulds, G. S. Walker, J. C. Jones, B. F. Gray, in: Chemeca 92: The Impact of Government Policy on the Process Industries, Official Conference Proceedings, Parkville, Royal Australian Chemical Institute, 1992, 67-73.

[43] J. W. Chun, R. G. Anthony, Ind. Eng. Chem. Res., 1993, 32, 788-795.

[44] D. J. Thomas, R. Willi, A. Baiker, Ind. Eng. Chem. Res., 1992, 31, 2272-2278.

[45] N. R. Hunter, H. D. Gesser, L. A. Morton, P. S. Yarlagadda, D. P. C. Fung, Appl. Catal., 1990, 57, 45-54.

[46] T. Baldwin, R. Burch, G. Squire, S. Tsang, Appl. Catal., 1991, 74, 137-152.

[47] N. Fukuoka, K. Omata, K. Fujimoto, in: Pacifichem '89, Abstract, Conference Proceedings, 1989, 135, 106-107.

[48] P. S. Yarlagadda, L. A. Morton, N. R. Hunter, H. D. Gesser, Ind. Eng. Chem. Res., 1988, 27, 252-256.

[49] V. S. Arutyunov, V. M. Rudakov, V. I. Savchenko, E. V. Sheverdenkin, O. G. Sheverdenkina, A. Yu. Zheltyakov, Theor. Found. Chem. Eng., 2002, 36, 472-476.

[50] R. S. Burch, G. D. Squire, S. C. Tsang, J. Chem. Soc., Faraday Trans.1, 1989, 85, 3561-3568.

[51] M. J. Foral, Preprints-American Chemical Society, Division of Pe- 


\section{Graphical Abstract}

Chin. J. Catal., 2016, 37: 1206-1215 doi: 10.1016/S1872-2067(15)61097-X

A review of the direct oxidation of methane to methanol

Baozhai Han, Yang Yang, Yanyan Xu, U. J. Etim, Benjing Xu* , Zifeng Yan* China University of Petroleum (East China)

This review presents the advancements in the process of direct oxidation of methane to methanol by heterogeneous and homogeneous oxidation and analyses the advantages and disadvantages of each process, suggesting the future development direction simultaneously.

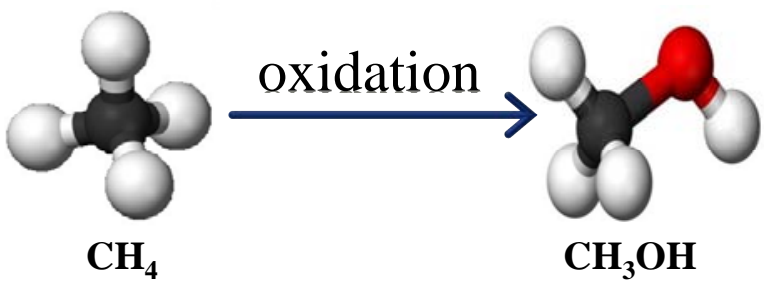

troleum Chemistry, 1992, 37, 34-40.

[52] V. S. Arutyunov, V. M. Rudakov, V. I. Savchenko, E. V. Sheverdenkin, Theoret. Found. Chem. Eng., 2005, 39, 487-492.

[53] I. G. Fokin, V. I. Savchenko, V. S. Arutyunov, Russ. J. Phys. Chem. B, 2014, 8, 148-151.

[54] Y. Teng, H. Sakurai, K. Tabata, E. Suzuki, Appl. Catal. A, 2000, 190, 283-289.

[55] T. Li, S. J. Wang, C. S. Yu, Y. C. Ma, K. L. Li, L. W. Lin, Appl. Catal. A, 2011, 398, 150-154.

[56] R. A. Periana, D. J. Taube, E. R. Evitt, D. G. Löffler, P. R. Wentrcek, G. Voss, T. Masuda, Science, 1993, 259, 340-343.

[57] X. Gang, H. Birch, Y. M. Zhu, H. A. Hjuler, N. J. Bjerrum, J. Catal., 2000, 196, 287-292.

[58] R. A. Periana, D. J. Taube, S. Gamble, H. Taube, T. Satoh, H. Fujii, Science, 1998, 280, 560-564.

[59] R. Palkovits, C. von Malotki, M. Baumgarten, K. Müllen, C. Baltes, M. Antonietti, P. Kuhn, J. Weber, A. Thomas, F. Schüth, ChemSusChem, 2010, 3, 277-282.

[60] R. A. Periana, O. Mirinov, D. J. Taube, S. Gamble, Chem. Commun., 2002, 2376-2377.

[61] X. Gang, Y. Zhu, H. Birch, H. A. Hjuler, N. J. Bjerrum, Appl. Catal. A, 2004, 261, 91-98.

[62] K. Cao, [MS Dissertation], Northwest University, Xi'an, 2004.

[63] C. J. Jones, D. Taube, V. R. Ziatdinov, R. A. Periana, R. J. Nielsen, J. Oxgaard, W. A. Goddard, Angew. Chem. Int. Ed., 2004, 43, 4626-4629.

[64] X. C. Zhang, K. Cao, L. Y. Chen, Y. Y. Han, Petrochem. Technol,, 2004, 33, 813-815.

[65] G. C. Yin, Z. W. Xi, G. Y. Cao, X. F. Zhang, M. Li, Chin. J. Catal., 1997, $18,402-405$.
[66] L. Y. Chen, B. L. Yang, X. C. Zhang, D. Wu, X. P. Zhang, Chin. J. Catal., 2006, 27, 462-464.

[67] A. Sen, E. Gretz, T. F. Oliver, Z. Z. Jiang, New J. Chem., 1989, 13, 755-760.

[68] M. N. Vargaftik, I. P. Stolyarov, I. I. Moiseev, J. Chem. Soc., Chem. Commun., 1990, 1049-1050.

[69] I. Yamanaka, M. Soma, K. Oisuka, J. Chem. Soc., Chem. Commun., 1995, 2235-2236.

[70] M. Lin, T. Hogan, A. Sen, J. Am. Chem. Soc., 1997, 119, 6048-6053.

[71] E. Gretz, T. F. Oliver, A. Sen, J. Am. Chem. Soc., 1987, 109, 8109-8111.

[72] Z. J. An, X. L. Pan, X. M. Liu, X. W. Han, X. H. Bao, J. Am. Chem. Soc., 2006, 128, 16028-16029.

[73] J. L. Yuan, Y. Wang, C. J. Hao, Catal. Lett., 2013, 143, 610-615.

[74] N. F. Gol'dshleger, M. B. Tyabin, A. E. Shilov, A. A. Shteinman, Russ. J. Phys. Chem., 1969, 43, 1222.

[75] I. Bar-Nahum, A. M. Khenkin, R. Neumann, J. Am. Chem. Soc., 2004, 126, 10236-10237.

[76] A. B. Sorokin, E. V. Kudrik, L. X. Alvarez, P. Afanasiev, J. M. M. Millet, D. Bouchu, Catal. Today, 2010, 157, 149-154.

[77] C. Hammond, M. M. Forde, M. H. Ab Rahim, M. Hasbi, A. Thetford, Q. He, R. L. Jenkins, N. Dimitratos, J. A. Lopez-Sanchez, N. F. Dummer, D. M. Murchy, A. F. Carley, S. H. Taylor, D. J. Willock, E. E. Stangland, J. Kang, H. Hagen, C. J. Kiely, G. T. Hutchings, Angew. Chem. Int. Ed., 2012, 51, 5129-5133.

[78] A. E. Shilov, G. B. Shul'pin, Chem. Rev., 1997, 97, 2879-2932.

[79] G. V. Nizova, G. Süss-Fink, G. B. Shul'Pin, Tetrahedron, 1997, 53, 3603-3614.

[80] C. Li, L. Y. Chen, J. Zhang, T. Lei, P. Lei, Chem. Eng. (China), 2010, 38(7), 58-61.

\section{甲烷直接氧化制甲醇研究进展概述}

\section{韩宝斋，杨扬，许妍奸，U. J. Etim，乔 柯，许本静"，阎子峰 \\ 中国石油大学 (华东)化学工程学院重质油国家重点实验室, 山东青岛 266580}

摘要: 目前, 天然气转化为高附加值化工产品的应用越来越受到人们关注. 甲烷作为天然气的主要成分, 其转化和应用是 天然气化工领域的重要研究方向. 而甲烷直接氧化制甲醇长久以来一直是研究重点. 甲烷直接氧化制甲醇与传统的甲烷 二步法间接转化相比, 有节能和工艺简化的突出特点. 然而, 甲醇直接氧化制甲醇过程所面临的主要问题有: (1) 甲烷分子 的活化能很高, 需要苛刻的操作条件才能活化参与反应; (2) 反应进行的程度难以控制, 生成的甲醇会进一步被氧化生成较 多副产物, 大大降低甲醇收率. 因此, 高效活化甲烷分子和抑制甲醇深度氧化是促进该过程工业化的重要研究内容.

本文主要论述了非均相、气相均相和液相体系中甲烷直接氧化制甲醇的研究进展. 在甲烷非均相氧化过程中, 采用过 渡金属氧化物作为催化剂在高温条件下催化甲烷部分氧化反应, 其中, 钼系和铁系催化剂的研究最为广泛. 研究表明, $\mathrm{MoO}_{3}$ 可作为催化剂的主要活性组分, 尤以 $\mathrm{MoO}_{3} / \mathrm{Ga}_{2} \mathrm{O}_{3}$ 催化剂性能最好, 得到甲醇收率最高. 在铁系催化剂中, Fe-ZSM-5 
催化反应的甲醇选择性和收率都相对较高; 但是每次反应后催化剂都需要重新活化, 这种间歇性操作会增加成本, 不利于 工业化应用. 总之, 甲烷的非均相氧化过程存在易形成金属聚集体、催化剂选择性低以及甲醇收率低 (5\%) 等问题, 需要深 入系统地研究解决. 然而, 与非均相氧化过程相比, 操作较为简单的甲烷气相均相氧化作为目前最有工业前景的过程受到 越来越多关注. 在此过程中, 影响反应的主要因素有反应器、反应条件 (反应压力、反应温度和反应时间等) 以及添加的介 质等. 反应器的特殊设计需要考虑的方面有反应产物的分离与转移、反应热的移除以有效提高甲烷的转化率, 比如膜反应 器对物质的分离作用. 反应压力对反应过程的影响较为复杂. 基于动力学因素, 提高反应压力可以较大幅度地增加甲醇收 率, 同时最佳反应温度降低, 但是, 当压力高于 $8.0 \mathrm{MPa}$ 时, 设备成本消耗大幅增加. 另外, 研究表明, 进料中加入 $\mathrm{NO}_{x}$ 作为 添加介质可以提高甲烷转化率和甲醇选择性, 同时降低初始反应温度. 与前两个氧化体系相比, 液相均匀氧化过程能够获 得较高的甲烷转化率与甲醇选择性. 但是液相体系中强腐蚀性介质的使用增加了设备成本, 阻碍了该过程工业化的应用 进程. 因此, 促进液相体系工业化的关键就是开发绿色高效的催化剂.

关键词: 甲烷; 直接氧化; 甲醇; 多相氧化; 气相均相氧化; 液相催化氧化

收稿日期: 2016-02-28. 接受日期: 2016-04-01. 出版日期: 2016-08-05.

*通讯联系人. 电话: 18561601866; 电子信箱: xubenjing@upc.edu.cn

通讯联系人. 电话: (0532)86981296; 传真: (0532)86981295; 电子信箱: zfyancat@upc.edu.cn

基金来源：国家自然科学基金委员会-中国石油天然气股份有限公司石油化工联合基金(U1362202); 中国石油大学(华东)研究生 创新基金(YCXJ2016030).

本文的英文电子版由Elsevier出版社在ScienceDirect上出版(http://www.sciencedirect.com/science/journal/18722067). 